\title{
NGO-Ization and Human Rights Law: The CRPD's Civil Society Mandate
}

\author{
Stephen Meyers ${ }^{1,2}$ \\ 1 Law, Societies \& Justice Program, University of Washington, Box 353565, Seattle, WA 98195, USA; \\ sjmeyers@uw.edu; Tel.: +1-206-616-8151 \\ 2 The Jackson School of International Studies, University of Washington, Box 353565, Seattle, WA 98195, USA \\ Academic Editor: Anna Arstein-Kerslake \\ Received: 21 March 2016; Accepted: 6 May 2016; Published: 11 May 2016
}

\begin{abstract}
The Convention on the Rights of Persons with Disabilities (CRPD) is unique among international human rights instruments for including a "civil society mandate". Within the convention, disabled persons organizations (DPOs) are identified as having the responsibility to "be involved and participate fully in the monitoring process" of the CRPD. In response to this mandate, international funders, NGOs (non-governmental organizations), and networks committed to the CPRD have begun to implement capacity-building programs that target grassroots DPOs with the goal of ensuring they become advocates and monitors of the CRPD. While the goals of these capacity-building programs are admirable, they must be critically assessed. The NGO-ization theory within development studies offers a framework for analyzing the potential unintended consequences of donors providing new funding, NGOs providing training, and global networks integrating local partners. NGO-ization studies have identified how grassroots associations are co-opted by outside actors through formalization and professionalization processes that significantly alter local groups and alienate members, thus making those associations less representative and less responsive to local needs and interests. Human rights scholars and international organizations focused on the CRPD should incorporate an NGO-ization perspective into their research and project-implementation to ensure that grassroots voices are heard and local needs addressed.
\end{abstract}

Keywords: civil society; human rights law; non-governmental organizations; disabled persons organizations; capacity building; grassroots associations

\section{Introduction}

Law, obviously, is meant to change behavior. International treaties, including human rights conventions, are typically designed to change the behavior of the States Parties that have signed and ratified them. As such, socio-legal scholars researching human rights focus on the ways in which international rights instruments affect the actions of states in relation to their citizens. Indeed, Risse, Ropp, and Skikkink promoted this line of human rights research in their much-cited volume The Power of Human Rights: International Norms and Domestic Change (1999) by asking "Have the principles articulated in the Declaration (Universal Declaration of Human Rights) had any effect at all on the actual behavior of states towards their citizens?" ([1], p. 1). In turn, socio-legal researchers have alternately answered this question in the affirmative and in the negative, with human rights champions often pointing to the most successful cases and human rights critics pointing to the worst disasters. A more nuanced response to Risse, Ropp, and Sikkink's question, however, has emerged: Human rights success in altering states' behavior depends on an effective civil society.

International human rights laws do not succeed by themselves but only when there is an active global civil society promoting those rights abroad and a vibrant national civil society advocating for those rights on the ground. For example, the presence of non-governmental organizations (NGOs) 
and transnational civil society networks is perhaps the most important correlation between state compliance and human rights treaty ratification [2,3]. Keck and Sikkink's Activists Beyond Borders (1998) provides the classic account as to why grassroots organizations in non-compliant countries are able to link with international groups that in turn can "name and shame" human rights violators and call upon other states and organizations to apply pressure and bring violating states into line [4]. Smith-Cannoy (2012) builds upon this line of argument by demonstrating that, while many states may adopt human rights instruments with no real intention of implementing them, the treaties themselves often empower and embolden local civic activists to begin filing complaints for violations and thus ultimately holding their states accountable [5]. This monitoring process has increasingly become institutionalized in international human rights instruments through optional provisions for treaty implementation that involve the right of citizens and civil society to report violations. These optional provisions, in fact, are a statistically significant factor in predicting the compliance of states with human rights standards [6]. What is overlooked, however, is that monitoring and complaint provisions within international treaties not only impact states, but also civil society, as well often reshaping local civil societies in profound ways.

The 2006 Convention on the Rights of Persons with Disabilities (CRPD) is not only the exemplar but the most advanced human rights treaty in terms of integrating a role for civil society and specifying the practices those civic associations should engage in. Not only does the CRPD's Optional Protocol allow the United Nations Committee on the Rights of Persons with Disabilities to "receive and consider communications from or on behalf of individuals or groups" (Article 1), but a monitoring role for persons with disabilities and their representative organizations is specified in the text of the Convention itself. As Maya Sabatello, international disability rights lawyer and permanent civil society representative to the UN on disability rights, writes:

Although participation of NGOs and civil society organizations in human rights debates and enforcement has been on the rise, particularly in the past couple of decades, there is no doubt that the disability rights movement has taken it to a new level. For the first time in an international human rights treaty, the expertise of those to be protected under the Convention, including their representative organizations, is fully recognized. Importantly, the Convention established an explicit positive legal obligation on states to seek their input in all levels of development, monitoring, and implementation of disability rights ([7], p. 23).

In this "groundbreaking provision" ([7], p. 23) not only are States Parties required to "consult and actively involve persons with disabilities...through their representative organizations" in Article 4, "General Obligations", but Article 33, "National Implementation and Monitoring", specifically mandates that "Civil society, in particular persons with disabilities and their representative organizations, shall be involved and participate fully in the monitoring process" of their human rights. Additionally, Articles 29, 34, and 40 also refer to a role for disabled persons organizations (DPOs) in the interpretation, implementation, and monitoring of their rights. In short, a rights advocacy role for civil society organizations made up of or representing persons with disabilities is written into the Convention itself.

While this innovation in the CRPD is certainly a victory for the global disability rights movement-the dozens of international NGOs and networks that successfully advocated for the creation and adoption of a human rights convention specific to persons with disabilities-it raises important socio-legal questions regarding the ways in which the treaty is reshaping local civil societies and DPOs on the ground. The intended effect of the inclusion of "persons with disabilities and their representative organizations" in a monitoring role in the CRPD is to ensure that there is both bottom-up (as well as top-down) pressure upon states to not only ratify the CRPD but to actively implement it. But this inclusion of a role for civil society also carries the potential of fundamentally changing the mission and practice of grassroots associations.

Many local disability associations in developing countries have heretofore prioritized self-help and social service provision over and above human rights advocacy [8,9]. Furthermore, many persons 
with disabilities view human rights with suspicion, associating its ideology with the legacy of Western intervention in the Global South [10] or simply do not identify with the social model of disability or politically identify as persons with disabilities despite being individuals with impairments [11].

International funders, disability NGOs, and global DPO networks committed to the success of the CRPD have anticipated this disconnect and begun to implement capacity-building programs around the world focused on transforming local DPOs into human rights advocates. The immediate goal of these programs is often implicitly, if not explicitly, to change the very nature of what activities and aims grassroots DPOs work towards, thus creating a "new kind of disability NGO_or amalgam of NGOs_-with a clear mandate to monitor human rights developments around the world" ([12], p. 179). While the specific objectives of these programs and the larger goal of integrating persons with disabilities into the monitoring and implementation of the CPRD are laudable, they raise important questions regarding the reshaping of grassroots civil society. What are the potential consequences of reorienting existing DPOs towards human rights advocacy? How does this change impact the persons with disabilities who are the members, volunteers, and beneficiaries of these local disability associations in their home communities? How can capacity-building programs be designed to ensure that local leaders continue to respond to members' priorities in context-specific ways rather than feel pressured to focus and utilize the objectives and global "best practices" introduced to them by international actors?

Because the civil society mandate within the CRPD is an unprecedented phenomenon, there has been very little research specific to the impact that human rights instruments have upon changing the behavior of grassroots civil society generally, much less DPOs. There is, however, existing literature in development studies on outside intervention in local civil societies. A large swathe of critical development studies theory falls under the rubric of "NGO-ization" [13], which is broadly concerned with the "institutionalization, professionalization, depolitization and demobilization of movements for social and environmental change" ([14], p. 1). This research perspective raises significant questions regarding the legitimacy [15], autonomy [16], and accountability [17] of local associations that receive aid or benefit from capacity-building initiatives sponsored by states, businesses, multilateral organizations, and international NGOs. These latter two-multilateral organizations and international NGOs-have played an important role in promoting the CRPD by partnering with grassroots DPOs around the world and supporting their human rights advocacy activities. The purpose of the article is to advocate for critical self-reflection among international disability rights advocates in the design and implementation of outreach programs. If grassroots DPOs are to remain connected to their local constituencies and the rights-based approach to disability is to succeed worldwide, the international disability rights community must be aware of both the positive and negative potential of funding, training, and partnership hold in terms of DPOs achieving their goals.

In this article, I argue that disability human rights law scholars must go beyond simply researching and analyzing the CRPD's impact on states to also include the CRPD's impact on civil society. In doing so, critical development studies scholarship, namely NGO-ization theory, provides an important way forward. In this article, I will review NGO-ization theory, analyze public statements, documents, and reports of international foundations, NGOs, and networks implementing capacity-building projects for DPOs in developing countries, and discuss implications for human rights, civil society, and disability studies researchers.

\section{NGO-Ization Theory}

The potential power of the CRPD is often seen as hinging on civil society's role in advocating for disability rights. As such, "disability awareness-raising and coordinated actions among disabled peoples' organizations are prerequisites for transforming the CRPD's promises into reality" ([18], p. 27). This human rights perspective on civil society reflects both the long-established participatory development paradigm [19], which focuses on grassroots associations as the foundation of both economic and political development, and the newer human rights-based [20] and inclusive [21] 
development paradigms, which focus on the empowerment of marginalized groups by integrating political advocacy into development planning and practice. This turn towards civil society in development and human rights has resulted in the prioritization of capacity-building activities [22] and funding [23] meant to strengthen civil society throughout the Global South. The unintended consequences or negative implications of this rapid rise of transnational capacity-building projects and partnerships, however, are rarely questioned, much less examined [24]. Strengthening civil society initiatives, paradoxically, may actually weaken the voices of marginalized groups at the local level and, in the case of DPOs, rendering them silent or circumscribing their advocacy to pre-determined scripts focused exclusively on the rights inscribed in the CRPD [25]. It is also linked with shifting grassroots groups' (and the international NGOs that have typically funded and supported them) focus and resources from meeting the short-range, material needs of members in the community to national or international advocacy initiatives that may yield few or no practical benefits in the immediate future [26-28], thus making members of these groups more vulnerable in the interim. In short, political advocacy does not necessarily help marginalized people, such as disabled persons, address their daily needs for food, shelter, and health care in the "here and now". The effects of NGO-ization - the formalization and professionalization of local civil societies—can be profound, yet are rarely systematically addressed within human rights-based approaches to social marginalization.

Capacity-building projects benefiting civic associations can, in fact, decrease their ability to adequately represent the needs and wants of their members. Chahim and Prakash, for example, argue that foreign funding and corresponding professionalization initiatives "creates dualism among domestic civil society organizations" ([17], p. 487), increasing the influence of "modern" NGOs, which are essentially local incarnations of international NGOs, and decreasing the profiles of grassroots, membership-based organizations that reflect local culture and traditional (and particular) associational models. This "modernization" of NGOs through NGO-ization processes is often a one-size-fits-all pursuit, where the organizational attributes that international groups help local groups develop are chosen "without consideration for economic, social and political context within which these issues arise" ([16], p. 193) even if other organizational models have proven effective in the local environment [29].

Factors driving the transformation of the grassroots associations into modern NGOs are: local groups developing dependence on foreign funding, integrating into hierarchical networks, increasing professionalization where local community members are replaced by trained professionals, and/or the taking of cues from outside, agenda-setting entities, such as influential international NGOs. Grassroots groups that do not succumb to NGO-ization are often ignored, if not made invisible, by outsiders who see them as backwards, lacking the legal and financial infrastructure (i.e., official certification or tax status) necessary for partnership, or simply do not recognize them as civic associations. "Formal NGOs", as opposed to the diversity of informal and formal associations based upon kinship, religious tradition, reciprocal relations, and self-help networks, however, are just one element of civil society, yet "often the part which external donors 'see' as civil society and find most bureaucratically amenable to engage with" ([30], p. 720). Thus, those groups most "in touch" with the people are sometimes the least likely to be listened to or included in larger discussions about the needs and interests of vulnerable groups.

In addition to the reordering of local civil societies, where certain types of grassroots associations are raised up over others, another principal concern within NGO-ization theory is that for those local groups that are targeted and chosen and whose "capacity" is built up by international organizations, there is a concomitant loss in autonomy and local accountability $[13,16,17]$. International organizations teach and "discipline" [31] grassroots groups through the provision of professional consultants and the communication of new ideas, both of which replace local leaders and existing beliefs about what needs to be done with alternatives that meet global, rather than local, expectations and interests. In essence, NGO-ization turns local organizations into satellites or franchises of international organizations, thus "de-localizing" them and pulling their leadership away from their members. 
Or, outsider organizations will simply enter the local organizations and "manufacture civil society" [30], establishing in communities entirely new organizations that reflect international values, yet are meant to represent local concerns. This can result in a "dislocated new civil society" ([32], p. 50) that has little connection to the actual populus, yet claims to speak for "the people" at the grassroots level.

Traditionally, NGO-ization research has focused on the ways in which local groups are co-opted by the "state and capital" [14], thus making them a part of the "development hegemony" [13] by which states and markets dictate the direction of political and economic development. What is often overlooked by development studies (and human rights researchers), however, is that the co-optation of grassroots associations goes far beyond governments and businesses to also include other civil society actors, such as international NGOs, foreign donors, and global networks, all of whom have an interest in having local partners who support their global agendas. The shaping of local civil society for this purpose thus requires some exercise of power; whether that power be hard or soft, it still has consequences. As Eschle has argued, "oppression and conflict within civil society and between social movement actors cannot simply be wished away or ignored" ([33], my emphasis, p. 74).

The result, however, is that attempts to build up grassroots associations can actually pull the rug out from under local civil society by alienating the very citizens who supposedly belong to it. Human rights, which has been so instrumental in advancing the rights of citizens around the world, can play a role in denuding local groups of the power to represent their members. Within grassroots groups themselves, elites can form, made up of leaders capable of interacting with the staff of international NGOs, leaving regular participants out of the conversation ([34], pp. 298-99). As Clifford Bob has noted, funding initiatives, for example, reward groups led by leaders with "marketing" savvy and the willingness to adopt the priorities of international donors, which can in turn pull local leaders away from their base in their quest for resources. Unfortunately, there is often an inverse relationship between the types of things local groups need to say and do to get international support and those things the members and beneficiaries of their organizations are saying or want done themselves, as "what plays best overseas seldom corresponds to what matters most domestically" ([26], p. 193).

In regards to networks, which often consciously adopt horizontal forms of participation, power still concentrates in the hands of the full-time, media savvy, or well-positioned (i.e., in Washington D.C. or Geneva) few who have the time or wherewithal to respond to calls or attend meetings with governments, multilateral organizations or other international NGOs. This can leave partners marginalized from the agenda-setting process ([35], p. 51; [36]) and lead to "oligarchy". Several critical studies of international NGOs [37] and transnational networks [36] have cited Michels' "iron law of oligarchy", first enunciated in his Political Parties: A sociological study of the oligarchic tendencies of modern democracy. In it, Michels argues that within ostensibly democratic parties representing their members, anti-democratic tendencies develop to deal with the "tactical and technical necessities" ([38], p. 365) of organizing and representation. An elite is formed, usually made up of an elected chair or council, in some cases "self-appointed" [36], who, for the sake of efficiency, begin to set agendas and make decisions without consulting their base.

A common response to these concerns above is for international NGOs, networks, and movements to commit to a greater "consciousness" regarding their activities. Consciousness, however, does little to address the underlying power differential between the Global North and Global South in terms of economic, cultural, and organizational resources. For example, studies on the international feminist movement have found that even when northern women's groups sought to "reverse the North-to-South flow of ideas and development strategies, the organization and its [southern] counterparts were circumscribed in locally-specific ways by the very power imbalances they were attempting to undo" ([39], p. 45). Not only do offers of grants and other forms of assistance "nudge" local groups into meeting outsiders' expectations, but capacity-training workshops provided by international NGOs are often activities with the explicit mission of bringing in new forms of social knowledge and identities (i.e., women-as-citizens) that displace local knowledge or silence alternative (and often more complex and intersecting) identities [40]. These sorts of changes can take place independently of NGO and 
network activities by being communicated by the law itself. Masaki [41], for example, shows how the UN Declaration on the Rights of Indigenous Peoples defines indigenous persons on the basis of outsider oppression (i.e., colonialization), a facet of their identity that may be far less important than gender, class, and even occupational group. As a result, rights protected in law and policies that pre-suppose a "shared will" on the basis of "shared oppression" silence intersecting and often marginalized identities within indigenous groups.

Transitioning from service-provision to political advocacy is one of the most important directions that international funders, NGOs, and networks, especially those centered on human rights, try to move grassroots associations. The service vs. advocacy divide is perhaps the most significant divide within civil societies, including global civil society. In a study of only formal NGOs that have contact with the UN system, Sikkink found that NGOs based in the North were far more likely to be in contact with the UN's human rights apparatus, such as the Human Rights Centre in Geneva, while southern NGOs were far more likely to be in contact with the UN's more service-oriented agencies, such as UNICEF and the UN Development Program ([42], p. 307). The split is even wider when informal NGOs are taken into account, including kinship networks, religious groups, and other forms of traditional association, many of which are based on norms of reciprocity and a focus on social support, self-help, charity, and/or mutual beneficence.

When grassroots groups are incentivized or pressured to adopt advocacy practices, their members are likely to resist. For example, in a study of "local survival initiatives" in Africa, Cheru warns that "the more the representatives of African social movements spend their time on worthy international [human rights] campaigns that are little understood by their own constituencies, and devote less time to critical local 'bread-and-butter and rights' issues, the more they risk losing legitimacy and fostering an ethic of isolationism" ([27], p. 125). However, perhaps the most significant effect is that these new professionalization activities focused on advocacy are replacing prior programming focused on training local individuals in providing substantive social and economic services (i.e., teacher or health care worker training) to marginalized populations. Rugendycke has observed that "where once NGOs concentrated their work on establishing projects to do things like build water supplies or encourage income generation, the same NGOs have increasingly devoted resources to advocacy campaigns directed at global actors" ([28], p. 2).This shift in funding focus is evident in training programs implemented in the Global South where a new class of professionals has been created who are adept in "watchdogging" government activities, but are unable to meet the more immediate material needs of their followers.

\section{Disabled Persons Organizations Capacity Building around the World}

The passage of the CRPD in 2006, with its important civil society mandate, has acted as a clarion call for international disability NGOs and global disability networks to reach out to local DPOs around the world, especially the Global South, to build their capacity and integrate them into their networks. In recognition of the fact that the CRPD established an "explicit positive legal obligation on states to seek ('representative disability organizations') input in all levels of development, monitoring, and implementation of disability rights" ([7], p. 23) international disability organizations have implemented funding, training, and other forms of outreach to local DPOs. The stated purpose of these activities is for DPOs to adopt a new, rights-based perspective on disability and to incorporate advocacy into their organizational practice. This new role for DPOs, thus, "involves a change in identity of the organization and in its strategic direction" in which "they now actively aim to convey the rights-based approach to disability" ([43], p. 369).

Changes in "identity" and the adoption of a new "strategic directions" can have both a positive and negative impact on the ability of DPOs to remain relevant in the lives of their members. I argue that capacity-building activities that formalize grassroots associations and orient their activities towards human rights advocacy and away from service-provision and other non-advocacy-related practices may succeed in bringing them in line with international priorities, but, if designed in ways that are 
not sensitive to local needs and contexts, could fail in terms of ensuring that their activities remain germane to their members. While it is important that local DPOs fulfill their responsibilities as outlined in the CPRD, their foremost responsibility is to the persons with disabilities that belong to them. As such, international capacity-building initiatives must be aware of their potential to NGO-ize local groups and, in fact, distance them from their memberships or render them ineffective in their specific social and political contexts. These processes are carried out through the creation of new funding opportunities, organizational development trainings, and integration into global networks, all of which have a narrow vision of DPOs around the world as supporters of the CRPD and, therefore, advocates. DPO research, unfortunately, has often been complicit in this process, dismissing local organizational diversity and dissidence, thus demonstrating the need for a critical development studies perspective in this era of transnational outreach towards civil society.

\subsection{Funding}

A wide array of international actors based in the Global North, ranging from government agencies for international cooperation through to disability and mainstream foundations and funds have begun funding DPOs in the Global South. The grant-giving criteria institutionalizes specific organizational forms and activities through funding priorities and eligibility requirements.

The majority of official foreign aid for DPOs is specific towards activities, limiting the money to only include "organizational capacity, advocacy efforts, cross-disability coalition building, coordination, and leadership and training" [44]. This holds both an implicit and explicit expectation that DPOs should be focused on advocacy rather than service provision or social support. These funds are also limited to formal DPOs. For example, the Australian Agency for International Development (AusAID)-funded Pacific DPO Fund specifies that grantees must "be non-governmental, non-profit and a DPO" and, furthermore, that "the organisation should have a plan to meet its purpose and objectives, a transparent organisational structure, clear administrative and financial systems to manage funds" [45]. These sorts of requirements create a selection-bias against less formal, traditional, and grassroots associations of persons with disabilities and towards professionalized groups that are "bureaucratically amenable" ([30], p. 720) for AusAID to partner with, even if these formal groups are both geographically and socially distant (i.e., in the capital and staffed by an educated elite) from the majority of persons with disabilities in the developing country they represent.

Both disability and mainstream international foundations prioritize disability rights advocacy over and above other forms of organizational practice. For example, the disability-specific Disability Rights Fund's grants program based in the United States explicitly states that its grants are to be used to "strengthen local stakeholders who can hold governments accountable for fulfilling the rights of persons with disabilities", and frames its grants program strategy in terms of the CRPD, stating "By supporting civil society efforts at country level to ratify, implement, and monitor the CRPD, DRF seeks to make a more direct impact on improving the conditions of (persons with disabilities)" [46]. The ABILIS Foundation of Finland similarly provides capacity-building grants to DPOs in developing countries, again framing their mission in terms of disability human rights advocacy: "ABILIS makes grants to carefully chosen DPOs in developing countries in order to strengthen the capacity of disabled peoples organizations (DPOs) in the global South so that they are better able to advocate for their Human Rights as articulated by the Convention on the Rights of Persons with Disabilities (CRPD)" [47]. Along with this advocacy priority, ABILIS also notes it only funds organizations with a formal "certificate of registration". In addition to these disability-specific foundations, mainstream funders such as the Open Society Foundation also emphasize human rights advocacy. Open Society explains its DPO grantmaking program as ensuring "persons with disabilities enjoy human rights on an equal basis with others" and outlining project activities as those that "tackle deeply entrenched discriminatory laws, practices, and attitudes that hinder full equality and inclusion of persons with disabilities" [48].

This prioritization of rights advocacy over service provision is, obviously, no accident, but, as shown above, explicitly linked to the CRPD, which provides a blueprint of what DPOs in developing 
countries should be doing. It may also display the historical experiences of the Northern (or Western) disability movements, where many of the needs for persons with disabilities were achieved through rights advocacy and legislative change, success that may not be as replicable in states where governments lack the institutional capacity to implement many of the rights they promise their citizens.

\subsection{Training}

A number of international disability NGOs, such as Action for Disability and Development, CBM International, and Handicap International have implemented global capacity-building projects aimed at increasing the rights advocacy and monitoring role of DPOs in developing countries. Virtually all programs directly reference human rights and the CRPD. The specific types of outreach ranging from organizing activities (i.e., bringing persons with disabilities together) through to consciousness raising and advocacy skill training.

Action for Disability and Development, an international NGO based in the United Kingdom, explains its approach as "We work with Disabled People's Organizations throughout Africa and Asia because the fight for equality starts with disabled people themselves", going on to outline a civil society outreach program wherein they "fight alongside disabled people's organizations and the disability movement to eradicate the injustice and the discrimination disabled people face" through activities such as organizing workshops, giving advice, and so forth.

CBM (Christian Blind Mission) International's International Advocacy and Alliances program is a global partnership program to promote human rights advocacy "within the guiding frameworks of the UNCRPD" (CBM 2013) that guides their activities around the world, specifying that "DPOs are a priority for capacity development by CBM, particularly in management and PCM (project cycle management)." As such, the focus is not only on advocacy, but also on professionalization-transforming grassroots advocates into project managers, presumably to implement projects funded by CBM or other international donors. In addition to CBM's direct outreach to DPOs, it also encourages other NGOs to do the same. In its Disability Inclusive Development Toolkit, which was developed as a guide for other international actors, it advises that groups assess DPOs in terms of the question: "Are people with disabilities able to exercise their right to be part of debate, advocacy and responsibility within their communities" ([49], p. 112) and, if not, building their capacity to do so. The toolkit explicitly outlines a human rights basis to its work and the civil society mandate in the CRPD, pointing to the importance of DPO involvement, because "A shadow/alternative report gives civil society an opportunity to have its voice heard on how the State is implementing the CRPD" ([50], p. 96).

Handicap International has its own global capacity-building campaign called Making It Work, which provides technical assistance to local DPOs in developing countries around the world to "strengthen their advocacy to influence social change". The "It" in Making It Work refers to the Convention on the Rights of Persons with disabilities. A Handicap International policy paper on supporting DPOs states that the CRPD constitutes a "roadmap for DPOs" and encourages them to use it, arguing that "the CRPD represents a major step, it is a tool that can be effective and make a difference for persons with disabilities only if used and enacted. This calls for all stakeholders to play their role to make these rights a reality" ([51], p. 16). The report goes on to advocate that DPOs are assisted in developing the "relevant capacities and resources" to become effective human rights advocates and that "DPOs have a responsibility" to do such advocacy. The policy paper goes on to explain that "HI has observed that in most developing countries there is a discrepancy between the important role that DPOs have to play and the limited opportunities, resources and capacities they have had to fulfill their role" ([50], p. 23) and to then outline project components meant to address the DPOs' (1) organization and technical weaknesses; (2) lack of awareness and knowledge of the "new conceptual models of disability developed at the international level"; (3) experience as human rights monitors; and (4) lack of actions that empower individual members ([50], pp. 23-64). Again, the role 
that DPOs are to play and the deficits identified are based on the CPRD and not the expressed needs or interests of persons with disabilities themselves within the targeted DPOs.

All of these programs are based on the global prioritization of the CRPD, an international instrument, rather than the expressed needs or mission of the DPOs targeted by these campaigns. The specific capacities strengthened range from project management through to human rights reporting, but not social service or self-help provision, the original purpose of many of the DPOs found in the world today. In that way, the local groups are engaged on the international NGOs terms, which are focused on their mission to ensure that DPOs are advocates for the CRPD. This, obviously, risks being a top-down process where grassroots groups are NGO-ized according to a globally-defined template.

\subsection{Network Integration}

Lastly, there are a number of global DPO networks, the two most prominent of which are hierarchical, moving from national to regional to the global network, which then claim to speak on behalf of persons with disabilities worldwide. For example, the International Disability Alliance (IDA) describes itself as "the most authoritative representative voice of persons with disabilities" ([51], p. 7) globally and Disabled People International (DPI), another global network, uses "A Voice of Our Own" as its motto, presumably also representing the voice of persons with disabilities around the world. These networks also emphasize unity in message, which they instill through their own capacity-building programs and guidance, much of which teaches regional and national coalitions how to be "good" network members by using the CRPD in advocacy and developing human rights monitoring reports that contribute towards the goals of global unity in message. This, however, may come at the cost of covering up diversity and regional and national particularity.

Disabled People International is the older of the two international DPO networks. DPI was founded in 1981 as a "human rights organization committed to the protection of the rights of people with disability and equal participation in society" and was instrumental in advocating for the CRPD. It claims over 130 member cross-disability DPOs. It was founded in the Global North, but has since expanded globally to include national DPOs that are then aggregated into regional DPO networks for North America, South America, Africa, Arab Nations, the Asia-Pacific, and Europe that are then members of the World Council and report to the world headquarters in Canada. Acknowledgement of diversity was present from the beginning of DPI. Jim Derksen, who was a disability advocate in Canada who believed in unity, argued to DPOs "Let us reason together, let us deliberate on our problems and needs, let us consider our abilities, and when we have agreed on the problems and solutions let us articulate our opinions and ideas in a strong and united voice" ([52], p. 1).

The idea of collectively agreeing upon problems and solutions, however, has not been achieved in DPI. In an extraordinarily honest report from DPI's World Council Meeting in Dhaka in 2015, which resulted in "withdrawing of confidence" in DPI's Chair, the report lays out its grievances, stating that "Most decisions in the name of DPI have been taken unilaterally by the chair without any approval by the World Council and consultation with the executive officers", listing such instances as the headquarters making "The unilateral announcement of controversial DPI political decisions in the United Nations and other platforms that undermined the unity of the disability movement without any approval from the executive officers", the "unconstitutional intervention in countries where DPI is established by revoking elected leadership and replacing it by a new one", and other complaints demonstrating a flagrant disregard to democratic norms within the organization [53].

The other global disability network is the International Disability Alliance, which was created in 1999 by seven transnational DPO networks and several disability NGOs that were principal advocates for the creation of a UN disability convention. In 2007, IDA changed into a global alliance of global and regional DPO coalitions and was subsequently given full consultative status within the UN, giving it an official advisory role on international disability rights. The mission of IDA is "to promote the effective and full implementation of the United Nations Convention on the Rights of Persons with Disabilities worldwide, as well as compliance with the CRPD within the UN system, through the active and 
coordinated involvement of representative organisations of persons with disabilities at the national, regional and international levels" [54]. This global coordination is promoted in two ways: direct advocacy capacity building and CRPD-reporting guidelines. The reporting guidelines for parallel reports, which are outlined as a responsibility of civil society in the CRPD, contain recommendations that paradoxically "ensures that issues that are important to small organizations are given a voice", but also ensure that DPOs submitting to the report speak with a "unified voice" and only submit "one comprehensive report" ([51], p. 28), thus creating obstacles to DPOs focused on community or disability-specific issues [25]. The report is also based upon the CRPD, specifying specific rights to be addressed and how their implementation is to be measured. IDA also has its own capacity-building program that "includes long-term coaching of few national coalitions in the preparation of parallel reports, punctual trainings at national and regional for key DPO representatives and other stakeholders on the monitoring of CRPD" [55]. There are no public reports of dissent (or confidence) as there is for DPI, but a similar emphasis on unity of message is present in IDA as it is in DPI, but without acknowledgement of diversity.

Within global networks, there is cause for concern with "oligarchy", as Ghirmire [36] found with transnational networks, wherein a chair, as evidenced by DPI's Dhaka Statement, is empowered (or takes the power) to set agendas and make unilateral decisions without consultation of members. A critical development studies perspective is needed in the face of procedures and processes by which grassroots groups are integrated in international disability networks through hierarchical patterns (local-national-regional-global) that are meant to create a unity in message. Top-down capacity building and guidance, wherein network headquarters "coach" and "advise" and "guide" members groups have the potential to NGO-ize grassroots groups, thus shaping them according to global concerns rather than enabling them to be organic, bottom-up representations of their local memberships. The importance of network integration and the difficulty of including and consulting highly diverse groups of persons with disabilities around the globe potentially increases the risk of such networks misrepresenting their base, especially in the face of the bureaucratic complexity of representing those groups to the CRPD Council of Experts.

\subsection{Research Deficit}

Much of the current research on DPO capacity building fails to take a critical stance on funding, training, and network integration initiatives. Instead, much research specifically advises how international NGOs and other actors can better achieve their goal of turning local DPOs into advocates for the CRPD and becoming part of a worldwide movement.

For example, in a study on an organizational development initiative involving six disability-specific NGOs and DPOs in East Africa implemented by Light for the World, a Netherlands-based disability rights NGO, the authors describe how the "six organizations have translated the legal responsibilities enshrined in the CRPD into new activities" ([43], p. 362) for the purposes of lessons being applied to other DPOs making the transition around the world. While the authors note that, as the DPOs in the study began to focus increasingly on human rights activities, this "led to tensions with the beneficiaries" and the DPO's members were "afraid that their group would be forgotten", they then go on to uncritically and positively report that the changes were accomplished because "most employees of the organisations and their partners had found a collective drive, confidence and fostered the ambition to realise the new desired role" ([43], p. 371). From an NGO-ization perspective, however, the "collective drive and confidence" of the DPOs' staff and management to forge ahead despite resistance from their base supporters (i.e., persons with disabilities themselves) should raise questions about the costs of professionalization in member participation in organizational decision-making. Further in the article, the authors note that the DPOs were able to make these changes because of their ability to "market their new approach" ([43], my emphasis, p. 379) to funders, without questioning their usage of the term "marketing", a strategy Clifford Bob [26] 
suggested, as reviewed above, that can lead to grassroots leaders adopting the priorities of foreign funders over and above domestic audiences and local movement participants in the quest for resources.

In a different context, but with a similar outcome concerning the adequacy of pre-existing NGOs in low-income countries to advance the disability rights agenda, Sarah Phillips, an anthropologist studying the Ukrainian disability movement, states that contemporary DPO coalitions in Eastern Europe are "plagued by socialist legacies" because "these groups have unwieldy, rather ossified structures and tend to have a narrow focus on shoring up social programs for certain groups of the disabled" ([56], p. 283). She sees this as antithetical to the human rights approach she supports for DPOs in the age of the CRPD. In her concluding remarks, Phillips suggests that Ukrainian NGOs need to pursue more international partnerships so that they have the "opportunities to travel to the United States, Canada, and other countries to participate in seminars, meet fellow activists, and become familiar with different approaches to rights issues" ([56], p. 291) and also "pursue international partnerships that can teach them a new model" ([56], p. 283). In short, she wants these groups to change and be brought in line with international, rather than local, priorities.

Research such as this is based on a northern priority of encouraging DPOs to take up their responsibilities under the CPRD as rights advocates, regardless of local priorities or purposes of organizing. It fails to integrate a critical development studies perspective that could open up important questions about international funder, NGO, and network interventions into local civil societies and the possible consequences that may have for those groups to remain connected to and answerable to their local members. An example of the latter is important.

One critical exception to the predominant DPO research is a consultancy report on capacity-building initiatives implemented by Northern DPOs and NGOs for grassroots DPOs in Mozambique. By taking an unbiased research position, the author demonstrates why an NGO-ization perspective is necessary to uncover real issues in the interactions between DPOs and international actors. The author reports that the initiatives of the international actors working in Africa often overlook the needs of local groups, noting that local DPOs saw "Northern NGO partners as concentrating their limited support on technical inputs, without paying attention to how organisations survive from day to day" and also "expressed anger at what they saw as unequal power with their Northern NGO partners" and that the local "DPOs reported feeling as if they are treated more like clients or objects than the primary constituency" [57], often noting that they were used by the North to fundraise for monies the Mozambique NGOs only benefitted from indirectly. In this case, rather than call for the local DPOs to fall in line, the consultant suggests that the international NGOs should question their practices. This is the sort of research where NGO-ization theory, which questions international funder, $\mathrm{NGO}$, and network practices from the beginning is helpful in highlighting local voices rather than global agendas.

\section{Implications and Conclusions}

Human rights instruments can offer a blueprint of what civic associations should be doing by specifying "communication" (or complaint) processes and spelling out the specific issues (i.e., rights and violations) and "identities" (i.e., definitions of specific groups) that local organizations should pay attention to and represent. Equally, if not more importantly, global human rights campaigns led by international donors, professional NGOs, and transnational networks often implement civil society capacity-building programs meant to educate and empower local civil societies by teaching marginalized groups about their rights and building up grassroots associations operating on the ground by providing small grants, holding workshops and training, and integrating those groups into transnational networks. These activities, however, can fundamentally reshape local civil societies by prioritizing some groups over others and implicitly (or explicitly) setting organizations' agenda.

The civil society mandate in the CRPD has made grassroots DPOs targets for change. While human rights protecting persons with disabilities are vital, the consequences of DPOs being specified within the convention as monitors must be investigated. The transformation of local associations may 
not be an unmitigated good-it may also have negative consequences in terms of the ability of local members to continue to exercise ownership over the groups that they have joined and supported, often for decades before the CRPD was written and signed and ratified around the world. In many cases, DPOs are critical service providers and social support mechanisms that persons with disabilities in poor communities rely on. A shift towards advocacy is often a shift towards a long-term strategy where recognition of disability rights by states will eventually address needs and create opportunities for disabled persons. But it may have short-term, or in the case of states with limited capacity, long-term consequences when DPOs shift their time, resources, and attention towards advocacy over and above their founding purpose to provide material assistance to their members. As such, these groups can, in fact, work against the very people they claim to represent.

NGO-ization theory within critical development studies raises important questions regarding the way grassroots associations can be co-opted by other actors, including representatives of global civil society such as foreign donors, international NGOs, and transnational networks. Utilizing this perspective is important to ensure that the voices of all persons with disabilities are heard and not simply an international elite. It also holds the promise of better allocating resources, providing training, and organizing representation to and for local DPOs in a way that reflects their members' priorities, thus ultimately and organically strengthening grassroots civil society rather than transforming it in accordance with a pre-determined and global blueprint.

For the civil society mandate within the CRPD to truly be empowering for grassroots DPOs and for the unmet needs of persons with disabilities in the Global South to be met, the mandate's interpretation and implementation must be left to local groups. The international disability rights community can (and often does) play an important role in helping DPOs reach their full potential. It is, however, the responsibility of those involved in designing and implementing global capacity-building programs to engage in critical self-reflection so as to be aware of the power that funding, training, and other forms of assistance hold to both bring grassroots associations closer or to push grassroots associations further away from their memberships. Outside interventions should be assessed not only from the point of view of their ability to introduce and support a rights-based approach, but to allow local DPOs to interpret and integrate that approach in context-specific ways that remain focused on local priorities and can flexibly accommodate a range of interpretations and practices.

Conflicts of Interest: The author declares no conflict of interest.

\section{References}

1. Risse, Thomas, Stephen C. Ropp, and Kathryn Sikkink. The Power of Human Rights: International Norms and Domestic Change. Cambridge: Cambridge University Press, 1999.

2. Hafner-Burton, Emilie, and Kiyoteru Tsutsui. "Human Rights in a Globalizing World: The Paradox of Empty Promises." American Journal of Sociology 110 (2005): 1373-411. [CrossRef]

3. Simmons, Beth. Mobilizing for Human Rights: International Law and Domestic Enforcement. New York: Cambridge University Press, 2009.

4. Keck, Margaret, and Kathryn Sikkink. Activists beyond Borders. Ithaca: Cornell University Press, 1998.

5. Smith-Cannoy, Heather. Insincere Commitments: Human Rights Treaties, Abusive States, and Citizen Activism. Washington: Georgetown University Press, 2012.

6. Cole, Wade. "Human Rights as Myth and Ceremony? Reevaluating the effectiveness of human rights treaties, 1981-2007." American Journal of Sociology 117 (2012): 1131-71. [CrossRef]

7. Sabatello, Maya. "A Short History of the International Disability Rights Movement." In Human Rights $\mathcal{E}$ Disability Advocacy. Edited by Maya Sabatello and Marianne Schulze. Philadelphia: University of Pennsylvania Press, 2014, pp. 13-24.

8. Ingstad, Benedict, and Susan Whyte, eds. "Disability and culture: An overview." In Disability and Culture. Berkeley: University of California Press, 1995, pp. 1-37.

9. Turmasani, Majid. Disabled People and Economic Needs in the Developing World: A Political Perspective from Jordan. Hampshire: Ashgate Publishing, 2003. 
10. Meekosha, Helen, and Karen Soldatic. "Human Rights \& the Global South: The case of disability." Third World Quarterly 32 (2011): 1383-97.

11. Meyers, Stephen. "The Social Model of Disability Under the Shadow of the Revolution: Ex-Combatants Negotiating Disability Identity in Nicaragua." Qualitative Sociology 37 (2014): 403-24. [CrossRef]

12. Quinn, Gerard, and Theresia Degener. Human Rights and Disability. New York: United Nations, 2002.

13. Kamat, Sangeeta. Development Hegemony. New York: Oxford University Press, 2002.

14. Choudry, Aziz, and Dip Kapoor. NGOization: Complicity, Contradictions and Prospects. New York: Zed Books, 2013.

15. Howell, Jude, and Jenny Pearce. Civil Society and Development. Boulder: Lynne Rienner Publishers, 2001.

16. Nazneen, Sohela, and Maheen Sultan. "Struggling for Survival and Autonomy: The NGOisation of women's organizations in Bangladesh." Development 52 (2009): 193-99. [CrossRef]

17. Chahim, Dean, and Asseem Prakash. "NGOization, Foreign Funding, and the Nicaraguan Civil Society." VOLUNTAS: International Journal of Voluntary and Nonprofit Organizations 25 (2013): 487-513. [CrossRef]

18. Stein, Michael, and Janet Lord. "Forging Effective International Agreements: Lesson for the UN Convention on the Rights of Persons with Disabilities." In Making Equal Rights Real: Taking Effective Action. Edited by Jody Heymann and Adele Cassola. Cambridge: Cambridge University Press, 2009, pp. 27-50.

19. Mohan, Giles, and Kristian Stokke. "Participatory Development and Empowerment: The Dangers of Localism." Third World Quarterly 21 (2000): 247-68. [CrossRef]

20. Uvin, Peter. Human Rights and Development. Bloomfield: Kumarian Press, 2004.

21. Hickey, Sam, Kendall Sen, and Badru Bukenya. The Politics of Inclusive Development. Oxford: Oxford University Press, 2015.

22. Eade, Deborah. Capacity-Building: An Approach to People-Centred Development. Oxford: Oxfam, 1997.

23. Stiles, Kendall. "International support for NGOs in Bangladesh: Some unintended consequences." World Development 30 (2002): 835-46. [CrossRef]

24. Batliwala, Srilatha. "Grassroots movements as transnational actors: Implications for global civil society." Voluntas: International Journal of Voluntary and Nonprofit Organizations 13 (2002): 393-409. [CrossRef]

25. Meyers, Stephen. "Global Civil Society as Megaphone or Echo Chamber?: Formalizing voice in the international disability rights movement." International Journal of Politics, Culture, and Society 27 (2014): 459-76. [CrossRef]

26. Bob, Clifford. The Marketing of Rebellion: Insurgents, Media, and International Activism. New York: Cambridge University Press, 2005.

27. Cheru, Fantu. “The Local Dimensions of Global Reform.” In Global Futures: Shaping Globalization. Edited by Jan Nederveen Pieterse. New York: Zed Books, 2000, pp. 119-32.

28. Rugendycke, Barbara. NGOs as Advocates for Development in a Globalising World. London: Routledge, 2007.

29. Meyers, Stephen. "Disabled persons associations at the crossroads of two organizational environments: Grassroots groups as part of an international movement and a local civil society." Research in Social Science and Disability: Environmental Contexts and Disability 8 (2014): 3-31.

30. Howell, Jude, and Jeremy Lind. "Manufacturing civil society and the limits of legitimacy: Aid, security and civil society after 9/11 in Afghanistan." European Journal of Development Research 21 (2009): 718-36. [CrossRef]

31. Ebrahim, Alnoor. NGOs and Organizational Change: Discourse, Reporting, and Learning. New York: Cambridge University Press, 2003.

32. Machetti, Raffaele, and Nathalie Tocci. Civil Society, Conflicts, and the Politicization of Human Rights. Tokyo: United Nations University Press, 2011.

33. Eschle, Catherine. "Globalizing Civil Society? Social movement and the challenge of global politics from below." In Globalization and Social Movements. Edited by Pierre Hamel, Henri Lustiger-Thaler, Jan Nederveen Pieterese and Sasha Roseneil. Basingstoke: Palgrave, 2001, pp. 61-85.

34. Biekart, Kees. The Politics of Civil Society Building: European Private Aid Agencies and Democratic Transition in Central America. Amsterdam: Utrecht International Books and the Transnational Institute, 1999.

35. Della Porta, Donatella, Massimiliano Andretta, Lorenzo Mosca, and Herbert Reiter. Globalization from Below: Transnational Activists and Protest Networks. Minneapolis: University of Minnesota Press, 2006.

36. Ghimire, Kleber. Organizational Theory and Transnational Social Movements. New York: Lexington Books, 2011.

37. Fisher, William. "Doing Good? The Politics and Antipolitics of NGO Practices." Annual Review of Anthropology 26 (1997): 439-64. [CrossRef] 
38. Michels, Robert. Political Parties: A Sociological Study of the Oligarchical Tendencies of Modern Democracy. New York: Dover Publications, 1959.

39. Weber, Clare. "Women to Women: Dissident Citizen Diplomacy in Nicaragua." In Women's Activism and Globalization: Linking Local Struggles and Transnational Politics. Edited by Nancy Naples and Manisha Desai. New York: Routledge, 2002, pp. 45-63.

40. Thompson, Kirsten. “Women's Rights are Human Rights." In Restructuring World Politics: Transnational Social Movements, Networks, and Norms. Edited by Sanjeev Khagram, James V. Riker and Kathryn Sikkink. Minneapolis: University of Minnesota Press, 2002, pp. 96-122.

41. Masaki, Katsuhiko. “Recognition or Misrecognition? Pitfalls of Indigenous Peoples' Free, Prior, and Informed Consent." In Rights-Based Approaches to Development: Exploring the Potentials and Pitfalls. Edited by Sam Hicky and Diana Mitlin. Bloomfield: Kumarian Press, 2009, pp. 69-85.

42. Sikkink, Kathryn. "Restructuring World Politics: The Limits and Asymmetries of Soft Power." In Restructuring World Politics: Transnational Social Movements, Networks, and Norms. Edited by Sanjeev Khagram, James Riker and Kathryn Sikkink. Minneapolis: University of Minnesota Press, 2000, pp. 301-18.

43. Van Veen, Saskia, Barbara Regeer, and Joshe Bunders. "Meeting the Challenge of the Rights-based Approach to Disability: The Changing Role of Disability-Specific NGOs and DPOs." Nordic Journal of Human Rights 31 (2013): 359-80.

44. US Agency for International Development. "Uganda Request for Proposals." Available online: https:/ / www.fundsforngos.org/usaid/usaid-expanding-participation-of-people-with-disability-andstrengthen-the-capacity-of-disabled-peoples-organization/ (accessed on 2 March 2016).

45. World Blind Union. "Third Round of Pacific Disabled Persons Organisation Fund." Available online: http:/ / wbuap.org/index/funding/the-third-round-of-the-pacific-disabled-persons-organisationfund-pacific-dpo-fund (accessed on 3 March 2016).

46. Disability Rights Fund. "Grantmaking." Available online: http://www.disabilityrightsfund.org/ grantmaking (accessed on 15 July 2013).

47. ABILIS. "ABILIS Foundation Main Purpose." Available online: http://www.abilis.fi/index.php?option= com_content\&view=article\&id=9\&Itemid=18\&lang=en (accessed on 1 March 2016).

48. Open Society Foundation. “Disability Rights." Available online: https://www.opensocietyfoundations.org/ topics/disability-rights (accessed on 3 March 2016).

49. Al Ju'beh, Kathy. “Disability and Inclusive Development Toolkit." CBM, 2015. Available online: http:// www.cbm.org/article/downloads/54741/CBM-DID-TOOLKIT-accessible.pdf (accessed on 5 March 2016).

50. Geiser, Priscille, Stefanie Ziegler, and Ute Zurmuhl. "Support to Organisations Representative of Persons with Disabilities." Policy Paper 04, Technical Resources Division, Handicap International, Leon, France, July 2011. Available online: http://www.hiproweb.org/uploads/tx_hidrtdocs/SupportToDPO.pdf (accessed on 9 May 2016).

51. International Disability Alliance (IDA). Guidance Document: Effective Use of International Human Rights Monitoring Mechanisms to Protect the Rights of Persons with Disabilities. Geneva: IDA, 2010.

52. Derksen, Jim. “Editorial comment." Challenger 1 (1975): 1-2.

53. Disabled People International. "Dhaka Statement." Paper presented at World Council Meeting, Dhaka, Bangladesh, 28-30 June 2015.

54. Disabled People International. "About DPI." Available online: http://www.dpi.org/index.html (accessed on 1 March 2016).

55. Disabled People International. "Projects/Capacity Building Programme.” Available online: http://www. internationaldisabilityalliance.org/en/capacity-building-programme (accessed on 1 March 2016).

56. Phillips, Sarah. "Civil Society and Disability Rights in Post-Soviet Ukraine: NGOs and Prospects for Change." Indiana Journal of Global Legal Studies 16 (2009): 275-91. [CrossRef]

57. Ncube, Jabulani. “Capacity build of disabled people's organisations in Mozambique." Disability Knowledge and Research, 2005. Available online: http://r4d.dfid.gov.uk/PDF/Outputs/Disability/PolicyProject_ mozambique.pdf (accessed on 9 May 2016).

(c) 2016 by the author; licensee MDPI, Basel, Switzerland. This article is an open access article distributed under the terms and conditions of the Creative Commons Attribution (CC-BY) license (http://creativecommons.org/licenses/by/4.0/). 